\title{
Establishment of the International Criminal Court and the Role of USA: A Legal Appraisal
}

Saud Hassan*

In the prospect of an international criminal court lies the promise of universal justice. That is the simple and soaring hope of this vision. We are close to its realization. We will do our part to see it through till the end. We ask you...to do yours in our struggle to ensure that no ruler, no State, no junta and no army anywhere can abuse human rights with impunity. Only then will the innocents of distant wars and conflicts know that they, too, may sleep under the cover of justice; that they, too, have rights, and that those who violate those rights will be punished.

Kofi Anan, the then United Nations Secretary-General ${ }^{1}$

\section{Introduction}

In order to end global impunity of perpetration of heinous crimes against humanity and gross violation of human rights and to bring individual perpetrators to justice, international community felt the need for a permanent international criminal court. ${ }^{2}$ As the armed conflicts and serious violations of human rights and humanitarian law continue to victimize millions of people throughout the world, the reasons for an international criminal court became compelling. ${ }^{3}$ In many conflicts around the world, armies or rebel groups attack ordinary people and commit terrible human rights abuses against them. Often, these crimes are not punished by the national courts. Here the ICC is complementary to national criminal jurisdictions. ${ }^{4}$ The court only acts in cases where states are unwilling or unable to do so. ${ }^{5}$ The jurisdiction of the Court is not retrospective and binds only those States that ratify it. ${ }^{6}$ Unlike the International Court of Justice in The Hague, whose jurisdiction is restricted to states, the ICC has individualized criminal responsibility.

However, the role of USA regarding the establishment and continuation of ICC has caused the organization fall in a trouble. The better cooperation of

\footnotetext{
* Senior Judicial Magistrate, Rajbari, E mail: sauddu2004@yahoo.com

${ }^{1}$ http://www.un.org/law/icc/general/overview.htm, Accessed on June 8, 2009

${ }^{2}$ Md. Mohiuddin Khaled and M. Shaheen Chowdhury, 'Jurisdictional Problems of the International Criminal Court', The Chittagong University Journal of Law, Vol. VI, 2001, p. 1

${ }^{3}$ Dr. Mizanur Rahman, 'International Criminal Court (ICC): Revisiting its composition and cognizance Procedure', The Dhaka University Studies Part-F, Vol. IX (1), June 1998, p. 31

${ }^{4} \mathrm{http}: / /$ www.amicc.org/icc.html, Accessed on June 10, 2009

${ }^{5} \mathrm{http} / / /$ www.hrw.org/campaigns/icc/whowhat.htm, Accessed on June 10, 2009

${ }^{6}$ Supra Note 2, p. 2
} 
USA and other states could make the organization more active and effective as to its activities. The view of this paper is to analyze the role of USA towards the establishment, continuation and function of the International Criminal Court.

\section{Background of the Establishment of ICC}

Proposals for the establishment of an international criminal court have been under consideration for more than 50 years. Along with the convention for the prevention and punishment of terrorism, the League of Nations drafted, in 1937, a convention for the establishment of an International Criminal Court. After the establishment of the UN, proposals for the establishment of an international criminal court were once again considered and the matter was further pursued. ${ }^{7}$ The United Nations first recognized the need to establish an International Criminal Court, to prosecute crimes such as genocide. In Resolution 260 of 9 December 1948, the General Assembly, 'recognizing that at all periods of history genocide has inflicted great losses on humanity; and being convinced that, in order to liberate mankind from such an odious scourge, international co-operation is required,' adopted the Convention on the Prevention and Punishment of the Crime of Genocide. In the same Resolution, the General Assembly also invited the International Law Commission 'to study the desirability and possibility of establishing an international judicial organ for the trial of persons charged with genocide...' Following the Commission's report that the establishment of an international court to try persons charged with genocide or other crimes of similar gravity was both desirable and possible, the General Assembly established a committee to prepare proposals relating to the establishment of such a court. The committee prepared a draft statute in 1951 and a revised draft statute in 1953. The General Assembly, however, decided to postpone consideration of the draft statute pending the adoption of a definition of aggression. Since that time, the question of the establishment of an international criminal court has been considered periodically. In December 1989, in response to a request by Trinidad and Tobago, the General Assembly asked the International Law Commission to resume work on an international criminal court with jurisdiction to include drug trafficking. ${ }^{8}$

\footnotetext{
${ }^{7}$ Dr. S.K Kapoor, International Law And Human Rights, Central Law Agency, Allahabad, $13^{\text {th }}$ Ed. 2000 , p. 357

${ }^{8}$ Supra Note 1
} 
However, in 1992, the General Assembly directed the International Law Commission to elaborate a draft statute for an international criminal court. ${ }^{9}$ Then, in 1993, the conflict in the former Yugoslavia erupted, and war crimes, crimes against humanity and genocide -- in the guise of "ethnic cleansing" -once again commanded international attention. Shortly thereafter, the International Law Commission successfully completed its work on the draft statute for an international criminal court and in 1994 submitted the draft statute to the General Assembly. To consider major substantive issues arising from that draft statute, the General Assembly established the Ad Hoc Committee on the Establishment of an International Criminal Court, which met twice in 1995. After the General Assembly had considered the Committee's report, it created the Preparatory Committee on the Establishment of an International Criminal Court to prepare a widely acceptable consolidated draft text for submission to a diplomatic conference. The Preparatory Committee, which met from 1996 to 1998, held its final session in March and April of 1998 and completed the drafting of the text. At its fifty-second session, the General Assembly decided to convene the United Nations Diplomatic Conference of Plenipotentiaries on the Establishment of an International Criminal Court, subsequently held in Rome, Italy, from 15 June to 17 July 1998, 'to finalize and adopt a convention on the establishment of an international criminal court. ${ }^{, 10}$

The Statute outlining the creation of the court was adopted at an international conference in Rome. After 5 weeks of intense negotiations, 120 countries voted to adopt the treaty. Only seven countries voted against it (including China, Israel, Iraq, and the United States) and 21 abstained. 139 states signed the treaty by the 31 December 2000 deadline. 66 countries - 6 more than the threshold needed to establish the court - ratified the treaty on 11 April 2002. This meant that the ICC's jurisdiction commenced on July 1, 2002. ${ }^{11}$ As of May 3, 2004, 94 countries have ratified it. ${ }^{12}$ Bangladesh is the first signatory State from South Asia and third State from Asia that has signed the Statute of ICC but yet to be ratified it.

\section{Structure and Organs of the ICC}

\footnotetext{
${ }^{9}$ Resolution 47/33, http://www.ngos.net/un/icc.html, Accessed on June 12, 2009

${ }^{10}$ Supra Note 8 (Accessed on June 8, 2009)

${ }^{11}$ Supra Note 5

${ }^{12}$ Ibid
} 
This part of the paper will explore the composition of the ICC along with the discussion on the Presidency, the Chambers, Office of the Prosecutor, Office of the Registrar and the Registry, Assembly of the State Parties (ASP) and the election procedure of the Prosecutor and Judges.

\subsection{Composition of the ICC}

The International Criminal Court is based in The Hague, Netherlands. ${ }^{13}$ The Court may sit elsewhere, whenever it considers it desirable, as provided in the Statute. ${ }^{14}$ The Court can open field offices for investigations in other countries. It can also decide to hold hearings in a place that is closer to the site of the crime than The Hague. The Court has international legal personality. It also has such legal capacity as may be necessary for the exercise of its functions and the fulfillment of its purposes. ${ }^{15}$ According to the Statute of the ICC, the Court shall be composed of the organs of - (a) The Presidency;(b)An Appeals Division, a Trial Division and a Pre-Trial Division; (c) The Office of the Prosecutor and (d)The Registry. ${ }^{16}$

\subsection{The Presidency}

The President, together with the First and Second Vice-Presidents, constitutes the Presidency, which is responsible for-(a) the proper administration of the Court, with the exception of the Office of the Prosecutor; and (b) the other functions conferred upon it in accordance with this Statute. In discharging its responsibility the Presidency shall coordinate with and seek the concurrence of the Prosecutor on all matters of mutual concern. ${ }^{17}$ They are elected by the judges for a term of three years and have an option to be re-elected for once. The first Vice-President acts in the absence or disqualification of the President and the Second Vice-President acts in the absence or disqualifications of the above two. The whole administration of the international criminal court is run through this organ.

\subsection{The Chambers}

The judicial functions of the Court are carried out by Chambers. The Chambers are each composed of several judges. The Court has three Chambers, the Pre-Trial Chamber (with seven judges), the Trial Chamber

\footnotetext{
${ }^{13}$ The Rome Statute of the ICC, UN Doc.A/CONF.183/9, Article 3(1)

${ }^{14}$ Ibid, Article 3(3)

${ }^{15}$ Ibid, Article 4(1)

${ }^{16}$ Ibid, Article 34

${ }^{17}$ Ibid, Article 38(3) (4)
} 
(with six judges) and the Appeals Chamber (with five judges). Through these three Chambers the activities of the judges are distributed clearly in different stages of the proceeding of a case. This ensures fair hearing of trial that a judge sits only one stage of case and automatically stops sitting to hear appeal. The Pre-Trial Chamber decides whether the Prosecutor is allowed to start a formal investigation into a case. The Trial Chamber decides whether the accused person is guilty as charged and if they find him or her guilty, will assign the punishment for the crime and any damages to be paid to the victims. It also must ensure that a trial is fair and expeditious, and is conducted with full respect for the rights of the accused with regard for the protection of victims and witnesses. When the Prosecutor or the convicted person appeals against the decision of the Pre-trial or Trial Chambers, the case comes to the Appeals Chamber. The Appeals Chamber may decide to reverse or amend a decision, judgment, or sentence. It can also order a new trial before a different Trial Chamber. ${ }^{18}$

\subsection{Office of the Prosecutor}

The Office of the Prosecutor acts independently as a separate organ of the Court. It can appoint advisers with legal expertise on specific issues. ${ }^{19}$ It is responsible for receiving referrals and any substantiated information on crimes within the jurisdiction of the Court. ${ }^{20}$ The Office is headed by the Prosecutor. The Prosecutor has full authority over the management and administration of the Office, including the staff, facilities and other resources thereof. The Prosecutor is assisted by one or more Deputy Prosecutors. ${ }^{21}$ The Prosecutor and his Office gather information about crimes and present evidence against an accused before the Court. The Prosecutor's Office acts independently as a separate organ from the Court. ${ }^{22}$

\subsection{Office of the Registrar and the Registry}

The Registrar has the task of running the administration of the Court and keeping records. The Registry locates witnesses and victims and provides for their protection in participation during investigations and trials. ${ }^{23}$ The Registry

\footnotetext{
${ }^{18}$ Ibid, Article 39

${ }^{19}$ Ibid, Article 42(9)

${ }^{20}$ Ibid, Article 42(1)

${ }^{21}$ Ibid, Article 42(2)

${ }^{22}$ Ibid, Article 42

${ }^{23}$ http://www.hrw.org/backgrounder/africa/icc0904/2.htm\#_Toc79475339, Accessed on June 15, 2009
} 
is responsible for the non-judicial aspects of the administration and servicing of the Court without prejudice to the functions and powers of the Prosecutor in accordance with Article 42. The Registry is headed by the Registrar, who shall be the principal administrative officer of the Court. He/she exercises his or her functions under the authority of the President of the Court.

The judges elect the Registrar by an absolute majority by secret ballot, taking into account any recommendation by the Assembly of States Parties. The Registrar holds office for a term of five years with a scope for re-election once. The Registry can be regarded as the secretariat of the court that functions the administrative activities within the court that are necessary for smooth functioning of the court.

\subsection{Assembly of States Parties (ASP)}

The Rome Statute includes a provision for the establishment of an Assembly of States Parties (ASP or Assembly). According to the treaty, "each State Party shall have one representative in the Assembly who may be accompanied by alternates and advisers" and each State Party shall have one vote. All other States which have signed the Rome Statute or the Final Act of the Rome Conference may attend as observers. Note that the States Parties cannot interfere with the judicial functions of the Court. Any disputes concerning the Court's judicial functions are to be settled by a decision of the Court itself. ${ }^{24}$ The Assembly adopts its own rules of procedure. ${ }^{25}$

\subsection{Election of the Prosecutor and judges}

The Prosecutor as well as the judges are elected by the Assembly of State Parties, i.e. all countries that have ratified the Rome Statute. In February 2003, the first eighteen judges were elected, and in April 2003, the Prosecutor was elected. ${ }^{26}$ Only those states who have ratified the treaty are able to nominate and elect judges and prosecutors. ${ }^{27}$

\section{Jurisdiction of the International Criminal Court regarding Crimes and Criminals}

This part of the paper will include the total discussion regarding different kinds of jurisdiction of the ICC regarding crimes and criminals. The ICC shall

\footnotetext{
${ }^{24}$ Supra Note 13, Article 112(1).

${ }^{25}$ Ibid, Article 112(9).

${ }^{26}$ Supra Note 23

${ }^{27}$ Supra Note 5
} 
have the power to exercise its jurisdiction over persons for the most serious crimes of international concern, as referred to in this Statute. The jurisdiction and functioning of the Court shall be governed by the provisions of this Statute. ${ }^{28}$ The International Criminal Court shall have jurisdiction to prosecute over natural persons pursuant to this Statute and not States. A person who commits a crime within the jurisdiction of the Court shall be individually responsible and liable for punishment in accordance with this Statute. ${ }^{29}$ The Court shall have no jurisdiction over any person who was under the age of 18 at the time of the alleged commission of a crime.$^{30}$ Immunities or special procedural rules which may attach to the official capacity of a person, whether under national or international law, shall not bar the Court from exercising its jurisdiction over such a person. ${ }^{31}$ The jurisdiction of the Court shall be limited to the most serious crimes of concern to the international community as a whole. ${ }^{32}$ The ICC will have jurisdiction over crimes committed in the territories of ratifying states and over crimes committed anywhere by nationals of ratifying States. States that do not ratify the treaty can choose to accept the court's jurisdiction in particular cases. These states, and all states parties, must cooperate with the court's investigations and prosecutions. ${ }^{33}$ The crimes within the jurisdiction of the Court shall not be subject to any statute of limitations. ${ }^{34}$

The Rome Statute breaks with this tradition by providing that upon becoming parties to the Statute, states thereby, automatically accept the jurisdiction of the court with respect to all the crimes covered by the Statute. ${ }^{35}$ There is, therefore, no possibility of a state party accepting the jurisdiction over certain crimes and not others, or being required to consent to the exercise of jurisdiction on a case by case basis. ${ }^{36}$ There are four ways that cases can be brought to the International Criminal Court-a).by the Security Council of the United Nations; b) by a State party to the Statute; c) by the State in which the

\footnotetext{
${ }^{28}$ Supra Note 13 , Article 1

${ }^{29}$ Ibid, Article 25(1) (2).

${ }^{30}$ Ibid, Article 26.

${ }^{31}$ Ibid, Article 27(2).

${ }^{32}$ Ibid, Article 5(1).

${ }^{33}$ Supra Note 5

${ }^{34}$ Supra Note 13, Article 29.

${ }^{35}$ Ibid, Article 12(1), 36.

${ }^{36}$ Human Rights Watch, 'Summary of the key provisions of the ICC Statute', September, 1998
} 
crime took place; and d) by the Prosecutor acting on his/her own initiative. ${ }^{37}$ The prosecutor can start an investigation based on information that she or he receives from victims, non-governmental organizations, or any other reliable source. The ICC will rely on state cooperation in its investigation and prosecution of cases. The ICC does not have its own police force and will work side by side with national authorities. ${ }^{38}$

The ICC will never take preference of the jurisdiction of the national court it will act only when national court is unwilling or unable to arrange a trial for a criminal whose act is under any offence of the ICC Statute. For investigation and trial of a crime the ICC can take assistance from any state to handover a criminal to it.

\subsection{Crimes prosecutable by the ICC}

There are four categories of crimes within the court's jurisdiction: the crime of genocide (Article-6); Crimes against humanity (Article-7); War Crimes (Article-8); the crime of Aggression. The ICC has jurisdiction over three core crimes such as crime of genocide, crimes against humanity and war crimes. These are same crimes that were covered by the 1945 Nuremberg Charter (through which Nazis were prosecuted after WW II) as well as the Statutes of the International Criminal Tribunals for the former Yugoslavia and Rwanda. The first three crimes are carefully defined in the Statute to avoid ambiguity or vagueness. The Statute did not define the crime of aggression. ${ }^{39}$ The Rome Statute excludes prosecution of a person who was under the age of eighteen at the time of the alleged commission of a crime. Below are the brief definitions of the crimes as agreed in the Statute:

Genocide occurs when acts are "committed with intent to destroy, in whole or in part, a national, ethnical, racial or religious group." Such acts of genocide can be carried out by - (a) killing members of the targeted group;(b) causing serious bodily or mental harm to members of the group;(c) deliberately inflicting on the group conditions of life calculated to bring about its physical destruction in whole or in part; (d) imposing measures intended to prevent births within the group; (e) forcibly transferring children of the group to another group. ${ }^{40}$ The Rome Statute's definition of 'crime of genocide' is based

\footnotetext{
${ }^{37}$ Supra Note 13 , Article 38

${ }^{38}$ Supra Note 5

${ }^{39}$ Supra Note 2, p. 8

${ }^{40}$ Supra Note 13, Article 6
} 
on that of the Genocide Convention of 1948 and affirms that the crime is punishable not only when committed in armed conflict but also when committed in peace time. Genocide is genocide whenever and wherever it is committed. $^{41}$

Crimes against humanity are crimes that are "committed as part of a widespread or systematic attack directed against any civilian population." They can include acts such as-(a) murder (b)extermination (c) enslavement (d) deportation (e) forcible transfer of population (f) imprisonment (g) torture (h) rape (i) sexual slavery ( $\mathrm{j}$ ) enforced prostitution (k) forced pregnancy (l) enforced sterilization $(\mathrm{m})$ other forms of sexual violence (n)persecution against any identifiable group or collectivity (o) enforced disappearance of persons (p) the crime of apartheid and (q) other inhumane acts of a similar character intentionally causing great suffering, or serious injury to body or to mental or physical health. ${ }^{42}$ A broad description of crimes that cover crime against humanity also described in Article 7 of the Rome Statute.

According to Article 8 of the Rome Statute, War Crimes are divided in to two clusters: those committed in international armed conflict and those committed in non-international (or internal) armed conflict. ${ }^{43}$ War crimes in international armed conflicts consist of acts such as (i) willful killing, (ii) torture or inhuman treatment including biological experiments, (iii) willfully causing great suffering or serious injury to body or health; (iv) extensive destruction and appropriation of property, not justified by military necessity and carried out unlawfully and wantonly, (v) compelling a prisoner of war or other protected person to serve in the forces of a hostile power, (vi) willfully depriving a prisoner of war or other protected person of the rights of fair and regular trial, (vii) unlawful deportation or transfer or unlawful confinement and (viii) taking of hostages. ${ }^{44}$ An extensive form of war crimes also describes in article 8 of the Rome Statute.

War crimes in internal armed conflicts include acts such as: (1) violence to life and person, in particular murder of all kinds; (2) mutilation, cruel treatment and torture; (3) outrages upon personal dignity, in particular humiliating and degrading treatment; (4) taking of hostages and (5) conscripting and enlisting children under the age of fifteen years.

\footnotetext{
${ }^{41}$ Supra Note 2, p. 9

42 Supra Note 13, Article 7.

${ }^{43}$ Ibid, Article 8(2)(a), For internal armed conflict, see Article (8)(c) through (f)

${ }^{44}$ Ibid, Article 8
} 
In addition to the Geneva Conventions, other violations of the laws and customs of war can also be war crimes. The Rome Statute lists a wide range of such acts. Examples include- (1) intentionally directing attacks against the civilian population;(2) intentionally directing attacks against civilian objects; (3) intentionally directing attacks against personnel, installations, material, units or vehicles involved in a humanitarian assistance or peacekeeping mission and (4) killing or wounding a combatant who, having laid down his arms or having no further means of defence, has surrendered.. ${ }^{45}$ Under international law, such acts can be war crimes even if they are not committed as part of a systematic or widespread attack on civilians, but if they are only rare or sporadic. However, the authority of the International Criminal Court is more limited. According to the Rome Statute, "the Court shall have jurisdiction in respect of war crimes in particular when committed as part of a plan or policy or as part of a large-scale commission of such crimes".

\subsection{Territorial and Subject matter Jurisdiction of ICC}

There are some other jurisdictions of ICC like to prosecute crimes of sexual violence, to prosecute act of the recruitment and use of Child Soldiers. ICC has Jurisdiction to prosecute crimes committed by foreigners. As a general rule, a state comes within the ambit of the court's jurisdiction by becoming a party to it. However; non-party states may also accept the court's jurisdiction on a case-by-case basis. Under the Rome Statute the court may exercise it's jurisdiction over nationals of a non-party state "if the state in whose territory the crime occurred is a party to the Statute." 47 ICC has Jurisdiction to prosecute crimes committed by UN Peacekeeping Forces as well. This depends on the nationality of the peacekeepers. If the peacekeepers are from a country that has ratified the Rome Statute, they can be prosecuted. But peacekeepers from states that have not ratified the treaty are currently exempt from the Court's jurisdiction. This was decided by the U.N. Security Council in July 2002, and the rule was renewed for another year in June 2003. As a result, crimes committed by peacekeepers between July 14, 2002 and June 12, 2004 are exempt from the Court's jurisdiction (if the peacekeepers come from a country that has not signed or ratified the Rome Statute). This exception, however, has not been renewed after June $2004 .^{48}$

\footnotetext{
${ }^{45}$ Ibid, Article 8

${ }^{46}$ Ibid, Article 8(1)

${ }^{47}$ Supra Note 2, p. 7

${ }^{48}$ Ibid
} 
The ICC has no Jurisdiction to prosecute crimes from the past. No person shall be criminally responsible under this Statute for conduct prior to the entry into force of the Statute. ${ }^{49}$ If a country ratifies the Rome Statute later than July 2002 , the Court will only be able to prosecute crimes committed after the date of ratification. ${ }^{50}$

\section{Procedure of Investigation}

In this part of the research the procedure of starting an investigation, the Process before the Prosecutor to start an investigation and the relation and role of NGOs regarding investigation with ICC will also be discussed.

\subsection{Starting of investigation by the ICC}

The Prosecutor shall, having evaluated the information made available to him or her, initiate an investigation unless he or she determines that there is no reasonable basis to proceed under this Statute. ${ }^{51}$ States Parties shall, in accordance with the provisions of this Part and under procedures of national law, comply with requests by the Court to provide the assistance in relation to investigations or prosecutions according to the Statutes. ${ }^{52}$ There are three ways in which the Court can initiate investigations. First, a state that is party to the Rome Statute can refer a case to the Prosecutor of the Court. This is what the Ugandan government did in January 2004, about the situation in northern Uganda. In March 2004, the government of DRC referred crimes in the DRC to the Court. Second, the U.N. Security Council can refer a case to the Prosecutor. Third, the Prosecutor can initiate investigations into a case on his own initiative, based on credible information that he has received. This information can come from states, NGOs, victims, or any other source. The Court is likely to consider the gravity of the crime and the degree of individual responsibility for it. It will probably give priority to prosecuting persons accused of committing the most serious crimes and those who are suspected of being directly responsible for those crimes.

\subsection{Process before the Prosecutor to start an investigation}

In those situations where the Prosecutor decides to take action by himself, without a state referral, he first carries out a preliminary examination and then submits a request for authorization of a formal investigation to the Pre-Trial

\footnotetext{
${ }^{49}$ Supra Note 13, Article 24(1)

50 Supra Note 23

${ }^{51}$ Supra Note 13, Article 53(1)

${ }^{52}$ Ibid, Article 93(1)
} 
Chamber of the Court. In those situations where the Prosecutor receives a referral from a State Party, he must check whether the referral is admissible under the requirements of the Rome Statute and whether crimes under ICC jurisdiction appear to have been committed. If those criteria are satisfied, the prosecutor must launch an investigation to determine the persons bearing responsibility for the crimes committed. ${ }^{53}$

\section{Punishments awarded by the ICC}

In the event of a conviction, the Trial Chamber shall consider the appropriate sentence to be imposed and shall take into account the evidence presented and submissions made during the trial that relevant to the sentence. The sentence shall be pronounced in public and, wherever possible, in the presence of the accused. ${ }^{54} \mathrm{~A}$ person convicted by the Court may be punished only in accordance with this Statute. ${ }^{55}$ The Statute permits two types of penalties to the criminals: a) Imprisonment for a specified period; and b) Imprisonment for Life. ${ }^{56}$ The maximum sentence is life imprisonment. But imprisonment for life will not be over 30 years. Another mentionable thing is that there shall be a mandatory or compulsory review of the penalties when two-thirds of terms of total punishment for a crime or 25 years in case of a life imprisonment for a crime has been completed. The enforcement of a sentence of imprisonment in the host State is subject to the supervision of the Court and must be consistent with international standards governing treatment of prisoners, including the right of prisoners to be free of any torture or cruel, inhumane, or degrading punishment. $^{57}$

Requests for assistance shall be executed in accordance with the relevant procedure under the law of the requested State and, unless prohibited by such law, in the manner specified in the request, including following any procedure outlined therein or permitting persons specified in the request to be present at and assist in the execution process. ${ }^{58}$ The ordinary costs for execution of requests in the territory of the requested State shall be borne by that State, except as stated in the Statute, which shall be borne by the Court. ${ }^{59}$

\footnotetext{
53 Supra Note 23

${ }^{54}$ Supra Note 13, Article 76 (1) (4)

${ }^{55}$ Ibid, Article 23

${ }^{56}$ Ibid, Article 77

57 Supra Note 23

${ }^{58}$ Supra Note 13, Article 99(1)

${ }^{59}$ Ibid, Article 100(1)
} 
Subject to conditions which a State may have specified in accordance with article 103, paragraph 1 (b), the sentence of imprisonment shall be binding on the States Parties, which shall in no case modify it. The Court alone shall have the right to decide any application for appeal and revision. The State for enforcement shall not impede the making of any such application by a sentenced person. ${ }^{60}$ The enforcement of a sentence of imprisonment shall be subject to the supervision of the Court and shall be consistent with widely accepted international treaty standards governing treatment of prisoners. States Parties shall give effect to fines or forfeitures ordered by the Court under Part 7, without prejudice to the rights of bona fide third parties, and in accordance with the procedure of their national law. ${ }^{62}$ The State for enforcement shall not release the person before expiry of the sentence pronounced by the Court. The Court alone shall have the right to decide any reduction of sentence, and shall rule on the matter after having heard the person. ${ }^{63}$

\section{USA and the ICC}

One of the main purposes of this research is to focus the role of the USA in case of the establishment and functioning of ICC. In this part of the research will be included the Policy of USA to the ICC, US opposition to the ICC, US coalition with others to prevent the activities of ICC.

\subsection{U.S. Policy on the ICC}

The U.S. opposed the ICC from the beginning, surprising and disappointing many people. Human rights organizations and social justice groups around the world, and from within the US, were very critical of the U.S. stance given its dominance in world affairs. ${ }^{64}$ Until recently, the U.S. has had a history of involvement with the ICC. The U.S. delegation to the 1998 Rome Conference, which established the treaty creating the ICC, was the largest and most influential. In December 2000, before leaving office, President Clinton signed the Rome Treaty and expressed the importance of continued engagement with the ICC. He believed that cooperation with the Court was essential to addressing U.S. concerns and achieving U.S. objectives. ${ }^{65}$ USA signed the

\footnotetext{
${ }^{60} \mathrm{Ibid}$, Article 105

${ }^{61}$ Ibid, Article 106(1)

${ }^{62}$ Ibid, Article 109 (1)

${ }^{63}$ Ibid, Article 110 (1) (2)

${ }^{64} \mathrm{http}: / /$ www.globalissues.org/Geopolitics/ICC.asp, Accessed on June 12, 2009

${ }^{65}$ http:// usaforicc.org/policy.html, Accessed on June 14, 2009
} 
Rome Statute on 31 December of 2000. ${ }^{66}$ The U.S. did eventually signed up the ICC just before the December 2000 deadline to ensure that it would be a State Party that could participate in decision-making about how the Court works. ${ }^{67}$ Since taking office in 2000, however, President Bush adopted a stringent policy of isolation and opposition against the Court. In 2002, President Bush not only "unsigned" the Rome Statute - a legally ambiguous act - but also pushed for legislation such as the American Service Members' Protection Act (ASPA), which is dubbed the "Hague Invasion Act" by the European States. ${ }^{68}$ The U.S. has long been afraid of an international body having jurisdiction over the United States and that cases will be brought against U.S. civilian and military authorities on political grounds. ${ }^{69}$ President Bush's chief complaint against the ICC is that it will unfairly target US military personnel serving abroad. As Commander- in- Chief, he was worried that the thousands of US military forces currently deployed around the world would face trumped up charges of war crimes and the like by a politicized Court. Yet countless officials, both American and European, have assured President Bush that the Court is politically impartial, and furthermore, that even if US military personnel commit war crimes, crimes against humanity, or genocide, they are very unlikely to be hauled into the ICC. This is because the ICC is by definition a court of last resort, meaning that it will only try a national of a state that is unable or unwilling to prosecute that national. Because the US has a sound judicial system in place, in most cases the ICC will not have jurisdiction to try US military personnel. Yet of all the drastic measures it has taken since the Court's establishment in July 2002, none were as alarming as the administration's push for Bilateral Immunity Agreements (BIAs) to be signed between the US and state parties to the ICC. ${ }^{70}$

\subsection{US opposition to the International Criminal Court}

The USA is completely against the establishment and functioning of the ICC and defies its jurisdiction in all possible ways. It further goes to suggest for the setting up of a forum alternative to the court, i.e., kind of Truth and Conciliation Commission created in South Africa. The US concern is that its own nationals may be brought before the court without the consent of the

\footnotetext{
${ }^{66} \mathrm{http}: / /$ www.iccnow.org/?mod=romesignatures, Accessed on June 15, 2009

${ }^{67}$ Supra Note 64

${ }^{68}$ Supra Note 65

${ }^{69} \mathrm{http}$ ///www.globalissues.org/Geopolitics/icc/us.asp\#USunsignsTheRomeStatuteinMay2002, Accessed on June 12, 2009

${ }^{70}$ Supra Note 65
} 
United States government. ${ }^{71}$ For a number of reasons, the United States decided that the ICC had unacceptable consequences for their national sovereignty. Specifically, the ICC is an organization whose precepts go against fundamental American notions of sovereignty, checks and balances, and national independence. It is an agreement that is harmful to the national interests of the United States and harmful to its presence abroad. U.S. military forces and civilian personnel and private citizens are currently active in peacekeeping and humanitarian missions in almost 100 countries at any given time. It is essential that they remain steadfast in preserving the independence and flexibility that America needs to defend its national interests around the world. As President Bush said:

The United States cooperates with many other nations to keep the peace, but we will not submit American troops to prosecutors and judges whose jurisdiction we do not accept.... Every person who serves under the American flag will answer to his or her own superiors and to military law, not to the rulings of an unaccountable International Criminal Court. ${ }^{72}$

The Clinton administration participated actively in negotiations towards the International Criminal Court treaty, seeking Security Council screening of cases. If adopted, this would have enabled the US to veto any dockets it opposed. When other countries refused to agree to such an unequal standard of justice, the US campaigned to weaken and undermine the Court. The Bush administration, coming into office in 2001 as the Court neared implementation, adopted an extremely active opposition. Washington began to negotiate bilateral agreements with other countries, insuring immunity of US nationals from prosecution by the Court. As leverage, Washington threatened termination of economic aid, withdrawal of military assistance and other painful measures. These exclusionary steps clearly endanger the fledgling Court and may seriously weaken its credibility and effectiveness. The pursuit of bilateral immunity agreements was part of a long history of U.S. efforts to gain immunity for its citizens from the ICC. From 1995 through 2000, the U.S. government supported the establishment of an ICC, yet one that could be controlled through the Security Council or provided exemption from prosecution of U.S. officials and nationals. Purportedly, the Bush Administration believed that the Court could be used as a stage for political prosecutions, despite ample safeguards included in the Rome Statute to protect against such an event. Contrary to assurances from high-level U.S

\footnotetext{
${ }^{71}$ Supra Note 2, p 23

${ }^{72}$ http://www.state.gov/t/us/rm/15158.htm, Accessed on June 15, 2009
} 
officials, the U.S. is not respecting the rights of States that have ratified or acceded to the Rome Statute. As it did in seeking an exemption for peacekeepers from the jurisdiction of the ICC through the Security Council, the U.S. government is using coercive tactics to obtain immunity from the jurisdiction of the ICC for its nationals. U.S. officials have publicly threatened economic sanctions, such as the termination of military assistance, if countries do not sign the agreement. In several instances, there have been media reports of the U.S. providing large financial packages to countries at the time of their signature of bilateral immunity agreements.The U.S. government's so-called "Article 98" agreements have been constituted solely for the purpose of providing individuals or groups of individuals with immunity from the ICC. Furthermore, the agreements do not ensure that the U.S. will investigate and, if necessary, prosecute alleged crimes. Therefore, the intent of these U.S. bilateral immunity agreements is contrary to the overall purpose of the ICC, which is to ensure that genocide, crimes against humanity and/or war crimes be addressed either at the national level or by an international judicial body.It would appear then, that a key fear the US has in the ICC is that its own crimes (or support for such crimes) against humanity will be highlighted by an international institution if it is not under the control of the US (or, by proxy, the United Nations Security Council). This would then undermine the ability of the US to project its power around the world, something its neoconservative Bush Administration wanted to exploit as the sole remaining super power, as explained on this site's section on Military Expansion. ${ }^{73}$

In order to promote justice worldwide, the United States has many foreign policy instruments to utilize that are fully consistent with its values and interests. It will continue to play a worldwide leadership role in strengthening domestic judicial systems and promoting freedom, transparency and the rule of law. As former Secretary Powell has said, "We are the leader in the world with respect to bringing people to justice. We have supported a tribunal for Yugoslavia, the tribunal for Rwanda, trying to get the tribunal for Sierra Leone set up. We have the highest standards of accountability of any nation on the face of the earth."

The USA thinks that it respects the decision of States Parties to join the ICC, but they in turn must respect its decision not to be bound by jurisdictional

\footnotetext{
${ }^{73} \mathrm{http} / / /$ www.globalissues.org/Geopolitics/icc/us.asp\#USpressuringothernationsnottosurrender ortransferUSnationalstotheICC, Accessed on June 16, 2009
} 
claims to which it has not consented. As President Bush stated in his National Security Strategy, "We will take the actions necessary to ensure that our efforts to meet our global security commitments and protect Americans are not impaired by the potential for investigations, inquiry, or prosecution by the International Criminal Court, whose jurisdiction does not extend to Americans and which we do not accept. Signatories of the Statute of Rome have created an ICC to their liking, and they should live with it. The United States did not agree to be bound, and must not be held to its terms."

\subsection{US Coalition with others against ICC}

The US has not ratified the ICC Treaty after its demands that US citizens be exempt from prosecution were rejected. As the US seat at the ICC remains conspicuously empty, the international community should increasingly recognize the Bush administration's empty rhetoric in relation to its supposed commitment to international justice. It has become the site for a symbolic battle between law and politics for the US, a nation that believes that politics has priority over law. The Coalition suggests that the US leads a calculated campaign to weaken the Court. International law professor Harold Hongju Koh warns that the US's "hostile" attitude toward the ICC damages the international fight to hold war criminals accountable. The Bush administration is going to extremes to prevent the ICC from trying US soldiers, even withdrawing military aid to key allies. US efforts to weaken the ICC not only undercut the rule of law, they also make the world less safe for everyone, including US nationals. Amnesty International questions the legality of Security Council resolution 1422 which grants US citizens immunity from the ICC's jurisdiction. Resolution 1422 immunizes US nationals from investigation or prosecution by the ICC. Amnesty International opposes this resolution and explains why it goes against the UN Charter and other international law. They call on member states to reject a renewal of the resolution when it expires on June 30, 2003. In November 2005, the US showed flexibility in its attitude to the ICC when dealing with the crisis in Darfur. While claiming to acknowledge the importance of the ICC, the Bush administration still maintains a different approach to international law and multilateral institutions. US officials are now opposing any mention of the ICC in a Security Council resolution that seeks to protect civilians caught in armed conflicts.

\footnotetext{
${ }^{74}$ http://www.state.gov/t/us/rm/15158.htm, Accessed on June 15, 2009
} 
As the US maintains its stubborn opposition to the ICC, an increasing number of organizations and individuals urge Washington to rethink its position. In an attempt to reach a compromise, a group of 50 independent national security specialists have asked the EU to guarantee ICC immunity for US citizens if the country promises to support Sudan's referral to The Hague and restores aid to those governments that refused to sign a bilateral immunity agreement. ICC supporters consider such a deal unacceptable.

One of the key prongs in the Bush administration's campaign to undermine the ICC was the Security Council Resolution 1422. The resolution grants immunity to personnel from ICC non-states parties involved in U.N. established or authorized missions for a renewable twelve-month period. The Security Council adopted Resolution 1422 on July 12, 2002, following an intense debate on the U.N. Peacekeeping Mission in Bosnia-Herzegovina (UNMIBH).Human Rights Watch opposes Resolution 1422 for two reasons: (i) it grossly distorts the meaning of Articles 16 and 27 of the Rome Statute in ways that weaken the independence of the court; and (ii) by amending a multilateral treaty in this way the Security Council has overstepped its authority under the United Nations Charter. ${ }^{75}$

US opposition to the Court has gone beyond simply undermining human rights, and now threatens the UN's efforts to maintain world peace. The US continues to undermine the ICC by pressuring nations to sign bilateral agreements exempting US citizens from prosecution by the court. Latvia, Bulgaria and Malta are the latest targets, two of which require the US Congress to pass their NATO membership applications in 2004. An extradition treaty passed by the British parliament in December 2003 shields anyone extradited from the US to Britain from being handed over to the ICC. Critics argue that by accepting the treaty the British government bowed to American pressure to undermine the Court. The US, beyond merely "unsigning" the treaty to create the International Criminal Court, is now forcing small countries to sign bilateral deals granting immunity to US citizens. This report analyzes the damage to holding war criminals accountable. In Asia, the US successfully negotiated bilateral agreements to exempt US citizens from the ICC's jurisdiction. So far, thirteen states in Southeast Asia and five Central Asian republics have signed the US agreements. To date only five

${ }^{75}$ http://hrw.org/campaigns/icc/docs/1422legal.htm, Accused on June 14, 2009 
counties in the region accept the court's authority. 76 A fair reading of the treaty leaves one unable to answer with confidence whether the United States would now be accused of war crimes for legitimate but controversial uses of force to protect world peace. No U.S. Presidents or their advisors could be assured that they would be unequivocally safe from politicized charges of criminal liability. ${ }^{77}$

\section{Conclusion}

The ICC embodies the values and laws of democracy: human rights, due process, judicial transparency, accountability and the protection of victims. As a result, ICC member states are overwhelmingly democracies. United Kingdom, Canada, Australia, France, Germany, New Zealand, Italy, South Korea, Argentina, Jordan, South Africa, Japan, Russia, and Mexico, while not yet full members of the ICC, are also vocal supporters of the Court and its work. New democracies in Eastern Europe, Latin America, and Africa are among the ICC's strongest supporters. For these countries, joining the ICC helps build the rule of law and respect for human rights within their own borders, protecting against a return to tyranny and strengthening their democratic traditions. $^{78}$

However, it is very clear to all that the absentees - the USA, Russia, China, Israel and India has already weaken the ICC as to function its work which is to continue smoothly. So for the greater interest of the people of the world, to secure justice for all and to ensure conviction for the criminals under the statute of ICC, US should reconsider their approach towards ICC regarding immunities of their citizens and solders who are working in different states of the world as peacekeepers or others. This expectation rises to the highest height when some one like Barrack Obama takes the charge of US.

\footnotetext{
${ }^{76} \mathrm{http}: / /$ www.globalpolicy.org/intljustice/icc/usindex.htm, Accused on June 12, 2009

77 Supra Note 72

${ }^{78} \mathrm{http} / / /$ www.globalsolutions.org/programs/law_justice/icc/resources/courtofdemocracies.html Accessed on June 15, 2009
} 